\title{
August 1968 v politicko-ideologických heslách na stránkach dennej tlače
}

\author{
PATRÍCIA MolnÁROVÁ \\ Filozofická fakulta Univerzity Mateja Bela \\ v Banskej Bystrici
}

August 1968 in political and ideological slogans in daily paper

Abstract: The interdisciplinary oriented paper connects the linguistic, literary and media components against the background of the historical context. The study deals with political and ideological slogans published in the daily paper in 1968. It is structured into a theoretical part, which presents the basic terminological and contextual background, the function and meaning of political-ideological slogans in the press of the Communist party. The slogan is perceived here as a linguistic-communicative part of a specific language of the period of socialism, which was formed in an ideologically motivated space. On the other hand, the analysis focuses on the intertextual aspects of slogans and the basic motivic areas captured in it. The aim of the study is to reflect the events associated with the invasion of Warsaw Pact troops into Czechoslovakia through the intertextuality of slogans published from August 21 to September 21, 1968 in five Slovak dailies with national and regional validity. The analysis focuses on the intertextual motives of slogans and the basic motivic components from the field of politics, literature, culture or contemporary ideology captured in it.

Key words: 1968, Czechoslovakia, ideology, journalism, slogans, socialism, Soviet invasion.

DOI: https://doi.org/10.24040/ahn.2021.24.01.52-69

Tzv. socialistický experiment ${ }^{1}$ sa $\mathrm{v}$ priebehu viac ako štyridsiatich rokov rôznym spôsobom reflektoval v jazyku vytvárajúc jazykový obraz doby, politického režimu, osobností a udalostí, ktoré boli jeho súčast'ou. Na základe toho dnes v rámci lingvistického skúmania danej historickej etapy hovoríme o jazyku obdobia socializmu², o komunistickej reči, funkcionárskom jazyku, jazyku totality či jeho iných varian-

\footnotetext{
${ }^{1} \mathrm{~K}$ tomuto termínu porovnaj KALINOVÁ, L.: Společenské poměry v čase socialistického experimentu. Praha : Academia, 2007. 363 s.; KABÁT, J. Psychologie komunismu. Praha : Práh, 2011, s. 9-10; TŮMA, O.: Proměny komunistického režimu. In: ČERMÁK, F. - CVRČEK, V. SCHMIEDTOVÁ, V. (eds.) Slovník komunistické totality. Praha : Lidové noviny, 2010, s. 10. ${ }^{2} \mathrm{~V}$ lingvistických výskumoch používame termín jazyk obdobia socializmu v zmysle podoby, funkcie a významu komunikačného kódu uplatňovaného v oficiálnom diskurze rokov 1948 - 1989. Pomenovanie si nevyžaduje špecifikáciu, ked'že je vo svojej podstate odlišný od 
August 1968 v politicko-ideologických heslách ...

toch. ${ }^{3}$ Využívaným je tiež orwellovský termín newspeak, ktorý však nezobrazuje skutočný jazyka totalitného obdobia na našom území, ale na komparáciu predkladá jeho idealizovanú podobu. V našich výskumoch sa, naopak, sústred'ujeme primárne na reálnu podobu, funkciu a význam jazyka používaného v oficiálnom diskurze, ktorý skúmame prostredníctvom dobovej tlače. ${ }^{4}$ Predmet záujmu posúva naše bádanie na hranicu viacerých vedných odborov, v prvom rade lingvistiky a histórie, ale nemenej podstatné sú poznatky z oblasti mediológie, sociológie a psychológie, ktoré dopĺňajú obraz ideologicky podmienenej spoločnosti zodpovedajúcej podmienkam Československa do roku 1989. Interdisciplinárny náhl'ad na skúmanú problematiku, hoci primárne jazykovednú, umožňuje využívat' metódy a prístupy z d’alších vedeckých oblastí a tým ponúka nové výsledky a interpretácie siahajúce za hranice jedného odboru.

V rokoch 1948 - 1989 sa jazyk všeobecne, ale aj jeho špecifické výrazové prostriedky nevyužívali len ako komunikačný nástroj, ale slúžili ako zbraň, pomocou ktorej sa presadzovala a šírila oficiálna politická ideológia a propaganda. Výrazné postavenie v tomto smere zastávala oficiálna stranícka tlač predstavujúca mediálnu platformu komunistickej strany alebo iných politických či spoločenských organizácií, napr.

jazyka používaného v období fašizmu v 40. rokoch či demokracie po roku 1989. V kontexte historickej konkretizácie a vžitého dobového úzu však môžeme upresnit', že ide o tzv. reálny socializmus.

${ }^{3}$ Medzi základnými dielami venujúcimi sa problematike jazyka a komunikácie v totalitnom období Československých dejín uvedieme aspoň niekol'ko komplexných prác zo slovenského, českého a pol'ského prostredia, napr. BLAHO, M. - MERTOVÁ, N.: Sovietske reálie ako objekt lingvokulturologických výskumov. Prešov : Filozofická fakulta Prešovskej univerzity v Prešove, 2018. 100 s.; FIDELIUS, P.: Řeč komunistické moci. Praha : Triáda, 2016. 290 s.; SUK, J.: Zapomenutá slova. Připomínání totality prostřednictvím jazyka a hermenutiky. Frýdlant nad Ostravicí : Krtek a Datel, 2017. 177 s.; VÁŇA, T.: Jazyk a totalitarizmus. Brno : Centrum pro studium demokracie a kultury, 2013. 159 s.; GŁOWIŃSKI, M.: Nowomowa po polsku. Warszawa : PEN, 1991.146 s. a iné.

${ }^{4} \mathrm{~V}$ rámci doterajších interdisciplinárnych výskumov ide napr. o analýzu špecifických lexikálnych jednotiek v jazyku a zmeny ich významu pod vplyvom vonkajších politických a ideologických podmienok, charakteristiku ideológie socializmu zaznamenanú v tlači v podobe konceptuálnych metafor, výskyt a vplyv vlastných mien politických činitel'ov na formovanie oficiálneho diskurzu či dôsledky tematizácie politicko-ideologického diskurzu na podobu jazyka, napr. v prvomájových textoch. Bližšie pozri: MOLNÁROVÁ, P.: Kognitívno-sémantická interpretácia metafory v kontexte politicko-ideologického vývinu v rokoch 1965 - 1970. In: Slovenská reč, 84, 2019, č. 2, s. 185-204; MOLNÁROVÁ, P.: Hodnoty ideológie socializmu optikou vybraných lexém. In: Jazyk a kultúra, 2020, roč. 11, č. 41-42, s. 91-101; MOLNÁROVÁ, P.: Mocenské prejavy KSČ v reflexii vlastných mien v straníckej tlači. In: Acta historica Neosoliensia, tom. 23, č. 1, s. 52-71; MOLNÁROVÁ, P.: Jazykový obraz socializmu v kolektívnej pamäti súdobej a súčasnej publicistiky pod vplyvom roku 1968. In: Inskrypcje. Półrocznik, R. VIII, 2020, z. 2 (15), s. 47-59; MOLNÁROVÁ, P.: Vývin obrazu ideológie socializmu v tematickom diskurze: na príklade politicko-ideologickej konceptuálnej metafory. In: Nová filologická revue, 2020. [V tlači.]. 
Pravda - Orgán ústredného výboru Komunistickej strany Slovenska, Práca - Denník jednotného odborového hnutia, L'ud - Orgán strany národnej obrody, Smena - Orgán Slovenského ústredného výboru ČSM, Smer - Orgán stredoslovenského KV KSS a d'alšie.

V štúdii sa zameriavame na politicko-ideologické heslá a slogany v 60. rokoch ako jeden $\mathrm{z}$ charakteristických prejavov ideológie. K problematike pristupujeme zo širšieho uhla pohl'adu, predstaviac teoretickometodologické východiská pojmu heslo, resp. slogan a jeho zastúpenie a funkciu v jazyku obdobia socializmu. Konkrétnejšie sústred'ujeme pozornost' na vybraný úsek niekol'kých týždňov po vstupe piatich vojsk Varšavskej zmluvy do Československa v auguste 1968 a slogany publikované pri tejto príležitosti. Východiskový materiál na výskum predstavuje celoštátna aj regionálna denná tlač, ktorá vychádzala na Slovensku. Ciel'om príspevku je analyzovat' politicko-ideologické heslá reflektujúce jeden zo zásadných medzníkov socialistickej etapy československých dejín. Analýza je primárne kvalitatívna s dôrazom na oblast' sémantiky a s využitím princípu intertextovosti. ${ }^{5}$ Interpretačno-analytický prístup interdisciplinárne usúvzt'ažňuje lingvisticko-literárne a mediálne komponenty výskumu v historickom kontexte. Príspevok dopíňa bohatý súbor prác o udalostiach v roku 1968, v ktorom sa historický a politický kontext nachádza v sekundárnom postavení, pričom do popredia vystupuje jazykovo-tematický rámec skúmaného materiálu a jeho reflexia v dobových podmienkach.

\section{Historický kontext skúmanej problematiky}

Vzhl'adom na vymedzenú oblast' výskumu je nevyhnutným predpokladom d’alších analýz ukotvenie témy $\mathrm{v}$ historicko-politickom a najmä mediálnom kontexte. Je dôležité uviest', že ani v tzv. zlatých 60. rokoch sa režim diametrálne neodklonil od oficiálnej ideologickej línie, avšak postupným vývojom dochádzalo od roku 1963 k postupnému politickému, administratívnemu aj ideologickému uvol'ňovaniu. Už počas novotnovského obdobia realizujúceho marxisticko-leninskú, resp. stalinistickú politiku začalo postupne dochádzat' k prvým reformám, ktoré sa realizovali prostredníctvom reformne zmýšl’ajúcich intelektuálov v KSČ i mimo nej. Pozitívne zmeny v spoločnosti zasiahli do oblastí hospodárstva, kultúry, vzdelávania, trestného aj občianskeho práva. ${ }^{6}$

Obdobie 60. rokov teda nie je homogénnym sledom udalostí, ale podlieha vývojovým tendenciám, ktoré sa viac či menej odzrkadl’ujú v jazyku

\footnotetext{
${ }^{5}$ Intertextovost', syn. intertextualita je vlastnost' alebo stav textu vyplývajúci z prepojenia dvoch alebo viacerých textov. Intertextovost' pracuje v medzitextovými odkazmi.

${ }^{6}$ RYCHLÍK, J.: Československo v období socializmu. Praha : Vyšehrad, 2020, s. 168-202. 
oficiálneho mediálneho diskurzu. Do popredia pritom vystupujú momenty vymykajúce sa zaužívanej línii, akým bol aj rok 1968.

0. Tůma konštatuje, že dynamizácia spoločenského a politického života $v$ druhej polovici 60 . rokov je prejavom oneskoreného nástupu liberalizácie v Československu v porovnaní s okolitými krajinami patriacimi k socialistickému bloku. Emancipácia kultúrneho a mediálneho prostredia bola nasledovaná ekonomickou reformou aj rozpadom niektorých „prevodových pák režimu“, čo podl'a autora viedlo k „destabilizaci a fatálnímu rozvolnění režimu a takřka úplné ztrátě kontroly nad společností". ${ }^{7}$ Psychológ Kabát dodáva, že spoločnost' sa v rokoch smerujúcich k tzv. Pražskej jari nielen dynamizovala, ale zároveň sa v súvislosti s vývinom médií do podoby platformy pre slobodné vyjadrovanie názorov a postojov stávala náchylnejšou na kritiku. Rok 1968 označuje za „výbuch první erupce skutečné svobody od vzniku komunismu u nás". ${ }^{8}$ Išlo o krátke obdobie od januára do augusta, ked' sa spoločnost' začala od základov menit' a prikláňat' k demokracii, čo však nebolo predpokladom absolútneho vymiznutia dovtedy panujúceho strachu a kontroly, ako sme uviedli vyššie. Obdobie kariérneho vrcholu A. Dubčeka je charakteristické jeho snahou demokratizovat', humanizovat' a racionalizovat' československý politický systém pri zachovaní jeho sociálnej a ekonomickej podstaty, vytvorit' tak „socializmus s l'udskou tvárou“. V nevyhnutných sporoch s dogmatickým krídlom KSČ sa Dubček opieral o podporu verejnosti, ktorá sa po úprave tlačového zákona v marci 1968 nadšene zapojila do obrodného procesu. ${ }^{9}$

Vo vzt'ahu k médiám sa reformné tendencie prejavili novelizáciou Zákona č. 81/1966 Zb. o periodickej tlači a ostatných hromadných informačných prostriedkoch. ${ }^{10}$ Ked' bol zákon prijatý v roku 1966 (v platnosti od 1. januára 1966 do 27. júna 1968), podl'a časti 5 paragrafov 17 a 18 povol'oval činnost' Ústrednej publikačnej správy kontrolujúcej a vyhodnocujúcej obsah publikovaných príspevkov (predtým Hlavná správa tlačového dohl'adu). Prijatím tlačového zákona sa transformovala z neverejnej na verejnú inštitúciu, ktorej rozhodnutia boli legislatívne napadnutel'né a súdne vymáhatel'né. ${ }^{11} \mathrm{~V}$ prípade, že ich kontrolný

\footnotetext{
7 TŮMA, Proměny komunistického režimu, s. 12.

${ }^{8}$ KABÁT, Psychologie komunismu, s. 384.

9 JAŠEK, P. (ed.): August 1968. Fakty, osobnosti, udalosti. Bratislava : Ústav pamäti národa, 2020, s. 76-78.

10 Zákon je dostupný v plnom znení online: 81/1966 Zb. - Zákon o periodickej tlači a o ostat... - SLOV-LEX (slov-lex.sk) [cit. dňa 2. 4. 2021].

${ }^{11}$ BEDNAŘíK, P.: Médiá v Československu v letech 1945 - 1989 a jejich podíl na formování každodenního života obyvatel. In: PAŽOUT, J. (ed.): Každodenní život v Československu 1945/48 - 1989. Praha : Ústav pro studium totalitních režimů, 2015, s. 50-91.
} 
orgán uznal za porušujúce predmet štátneho, hospodárskeho alebo služobného tajomstva, ich publikovanie nebolo umožnené.

Následná novelizácia, ktorá bola platná od 28. júna 1968 do 25. septembra 1968, definovala cenzúru v časti 5 paragrafe 17 ako zakázanú. ${ }^{12}$ Zodpovednost' za obsah a kontrolu článkov preberal namiesto Ústrednej publikačnej správy šéfredaktor periodika. $V$ d'alšej novelizácii po augustových udalostiach roku 1968 (v platnosti od 26. septembra 1968 do 21. augusta 1969) bol odstránený paragraf rušiaci cenzúru a uzákonili sa nové represívne opatrenia zasahujúce do slobody vydávania periodickej tlače vrátane finančných trestov, čoho dôsledkom bola zvýšená autocenzúra ešte pred kontrolou zo strany štátu (v časti 2, paragraf 8). Tieto opatrenia ostali v platnosti aj po d'alšej novelizácii v roku 1969 a trvali v priebehu celého obdobia normalizácie. Znovuzavedenie cenzúry bolo jednou z Brežnevových podmienok počas moskovských rokovaní po invázii a následne bolo ukotvené $\mathrm{v}$ moskovskom protokole. Na publikovanie a vydávanie periodickej tlače od toho obdobia bolo nevyhnutné dôkladné kádrové vybavenie redakcie. Ďalšou podmienkou bol zákaz verejne používat' pojem okupácia. ${ }^{13}$

Historik J. Rychlík považuje Pražskú jar za medzník v nazeraní na socializmus v Československu a jeho interpretácii. Do augusta 1968 považuje vnímanie režimu za relatívne kladné a spojené s presvedčením, že vhodnými reformami by bolo možné odstránit' jeho defekty. Vpádom vojsk Varšavskej zmluvy na naše územie dochádza zároveň k výraznej modifikácii tohto postoja. Zmena kolektívneho pohl'adu sa prejavila stratou ilúzií o žiarivej budúcnosti a prednostiach socialistického režimu. Roky 1968 1969 sú interpretované bud' ako neúspešný pokus o reformu a demokratizáciu spoločnosti zmarený zahraničnou intervenciou, alebo ako vnútorný boj v komunistickej strane, ktorý demokratické sily v krajine využili na vlastné ciele. Druhý prezentovaný pohl’ad sa zároveň prikláňa $\mathrm{k}$ názoru, že demokratizačný experiment bol $\mathrm{v}$ daných podmienkach neuskutočnitel'ný a zlyhal by aj bez zásahu zahraničných faktorov. ${ }^{14}$

\section{Teoreticko-metodologické východiská výskumu}

Súčast'ou ideologickej agitácie ${ }^{15} \mathrm{v}$ období socializmu boli schematické, vopred pripravené a ideológiou schválené politické heslá nachádzajúce

\footnotetext{
12 Porovnaj novelizáciu 81/1966 Zb. - 81/1966 Zb. - Zákon o periodickej tlači a o ostat... SLOV-LEX (slov-lex.sk) [cit. dňa 2. 4. 2021].

13 JAŠEK, August 1968..., s. 137-138.

${ }^{14}$ RYCHLÍK, Československo v období socializmu, s. 191-192.

15 V období tzv. reálneho socializmu ide o synonymum termínu propaganda, ktoré sa používalo v krajinách východneho bloku. Pojem propaganda bol do roku 1989 využívaný primárne s odkazom na ideologickú a politickú manipuláciu spojenú so Západom. Analogicky k tomu sa v komunistických krajinách zaviedlo používanie termínu agitácia, ktorý neniesol
} 
August 1968 v politicko-ideologických heslách ...

sa tak vo verejnom priestore (napr. transparenty pri prvomájových manifestáciách), ako aj v médiách. ${ }^{16}$ Podl’a J. Davida sa v nich kumulovala propagandistická funkcia spolu so snahou o výchovu nového človeka ${ }^{17}$, v dôsledku čoho sa v jednotlivých etapách socializmu v heslách a sloganoch zdôrazňovali rôzne aktuálne hodnoty. ${ }^{18} \mathrm{Na}$ druhej strane slogan možno chápat’ aj ako charakteristickú súčast' publicistického jazykového štýlu, v rámci ktorého je „stále opakovanou myšlenkou, resp. [je to] dobové módní heslo vůbec“.19 Podl'a J. Krausa je to „zhuštěné, dobře zapamatovatelné vyjádření nápadné stránky definienda“.20 $\mathrm{Na}$ potreby d'alšej analýzy považujeme dvojicu heslo a slogan za synonymá. Heslo je v súčasnej slovnej zásobe chápané ako stručne formulovaná zásada alebo myšlienka, pričom rovnaký význam platil aj v dobovom výkladovom slovníku zo 60. rokov. M. Kochan zaoberajúci sa výskumom a analýzou sloganov v súčasnom pol'skom reklamnom a politickom diskurze však poukazuje na niektoré negatívne faktory vyplývajúce zo spojenia so schematickým a skostnateným jazykom obdobia tzv. reálneho socializmu. Upozorňuje, že ich používanie je späté so sémantickou vyprázdnenost'ou, významovým posunom, faktorom nepriatel'stva či s politickou ritualizáciou jazyka. Asociácia sloganov s jazykom obdobia socializmu ${ }^{21}$ v sebe nesie celý rad negatívnych konotácií, ako napr. neetický prístup,

žiadne negatívne konotácie. V československom priestore bola propaganda príliš úzko spätá s nacizmom a 2. svetovou vojnou, kým agitácia sa používala v zmysle ovplyvňovania verejnosti, špecificky aplikujúc personalizované persuazívne techniky. V oboch prípadoch, tak propagandy, ako aj agitácie napriek geopolitickej diferenciácii išlo o pomenovanie procesu využívajúceho rôzne stratégie a techniky za účelom dosiahnut' ideologicky prijatel’né výsledky v správaní a vnímaní recipienta. Na potreby štúdie používame oba termíny v synonymnom vzt'ahu. Podl'a: SRPOVÁ, H.: Manipulation and Persuasion. In: SRPOVÁ, H. BARTOŠEK, J. - ČMEJRKOVÁ, S. - JAKLOVÁ, A. - PÁCL, P.: Persuasion through words and images. Ostrava : University of Ostrava, Faculty of Arts, 2007, s. 36-37.

16 Porov. DAVID, J.: Hesla a slogany - na př́klade hesel k májovým dnům. In DAVID, J. ČECH, R. - DAVIDOVÁ GLOGAROVÁ, J. - RADKOVÁ, L. - ŠÚSTKOVÁ, H. Slovo a text v historickém kontextu. Perspektívy historickosémantické analýzy jazyka. Brno : Host, 2013, s. 183198.; ČERMÁK, F. - CVRČEK, V. - SCHMIEDTOVÁ, V. (eds.): Slovník komunistické totality. Praha : Lidové noviny, 2010, s. 25-29.; KNAPÍK, J. - FRANC, M. 2011. Průvodce kulturním děním a životním stylem v českých zemích 1948 - 1967. Praha : Academia, 2011. 1297 s.; PRUŠA, J.: Abeceda reálneho socialismu. Praha : Avia Consultansts, 2011. 678 s.

${ }^{17}$ S obdobím socializmu sa spája koncept nového socialistického človeka, v ktorom sú zosobnené najdôležitejšie hodnoty, ideály a postoje vyplývajúce z ideologického usporiadania spoločnosti. Tzv. nový socialistický človek predstavoval ideál inšpirovaný Sovietskym zväzom, ktorého podoby prenikli do oficiálneho diskurzu aj v Československu. K tomu pozri NEČASOVÁ, D.: Nový socialistický člověk. Československo 1948 - 1956. Brno : Host, 2018. 271 s.

${ }^{18}$ DAVID, Hesla a slogany..., s. 183-185.

${ }^{19}$ LOTKO, E.: Kapitoly ze současné rétoriky. Olomouc : Univerzita Palackého, 1999, s. 116.

${ }^{20}$ KRAUS, J.: Rétorika a řečová kultura. Praha : Karolinum, 2010, s. 75.

${ }^{21} \mathrm{~V}$ pol'štine sa používa termín nowomowa prevzatý z diela 1984 od G. Orwella. Porovnaj GLOWINSKI, Nowomowa po polsku, s. 7. 
manipuláciu, neobjektívnost' alebo nečestnost' vo vzt’ahu ku komunikačnému partnerovi.

Z psychologického hl'adiska vystupuje do popredia agitačná funkcia podmieňujúca ústup spontaneity. Prostredníctvom politických sloganov sa formovala a modelovala verejná mienka do režimom požadovanej, a teda oficiálne schválenej podoby. Politicko-ideologickým schematizmom determinované heslá znižovali, resp. výrazne limitovali individualitu jednotlivca a vzhl'adom na ich pravidelné opakovanie prispievali k prehlbovaniu vládnej propagandy v prijímatel'ovi. ${ }^{22}$ K základným vlastnostiam politicko-ideologických hesiel patrila jednoznačnost', monotónnost', krátkost' a jednoduchost' napomáhajúca rýchlemu zapamätaniu, a zároveň neumožňujúca vol'nú interpretáciu. Z formálnej stránky boli znázornené ako zvolanie alebo prianie, ich základ tvorilo sloveso v imperatíve alebo pluráli. Heslo zvyklo byt' zakončené výkričníkom, hoci to nebolo nevyhnutnost'ou. V prípade adjektív išlo o výrazy s hodnotiacou či oslavnou funkciou s ciel'om pôsobit' persuazívne. Z pragmatického hl'adiska sa zachovávala ideová polarizácia - heslá boli bud' výrazne pozitívne (obsahovo podporujúce domácu politiku a spojenecké krajiny, najmä Sovietsky zväz, ktorý v dobovej ideológii predstavoval vzor a nasledovaniahodný model), alebo výrazne negatívne (orientované $\mathrm{k}$ budovaniu nepriatel'a socialistického zriadenia - kapitalizmu, imperializmu, koloniálnej politiky západných mocností a pod.). ${ }^{23}$

Politicko-ideologické heslá a slogany sa vpredstavenej podobe a funkcii vyskytovali na stránkach dennej tlače v priebehu 60. rokov, a to i napriek zretel'nému kvantitatívnemu úbytku a obsahovej modifikácii v porovnaní s 50. rokmi. Periodiká v období socializmu mali štandardne v záhlaví titulnej strany ideologické heslo, zvyčajne Proletári všetkých krajín, spojte sa. V publicistických textoch, ktoré sú príznačné svojim mienkotvorným charakterom, hodnotiacim postojom a persuazívnymi tendenciami, však môžeme konštatovat', že ich zastúpenie bolo relatívne nízke. Ilustruje to príklad reprezentatívneho korpusu publicistických textov z denníka Pravda ${ }^{24}$, v ktorom sa nachádzalo iba štrnást' rôznych politicko-ideologických hesiel, z toho štyri sa vyskytovali v textoch publikovaných pri príležitosti Sviatku práce - 1. mája. Pravdu pritom možno považovat' za "výkladnú skriňu“ straníckej tlače na Slovensku. Napriek

\footnotetext{
${ }^{22}$ Platí tu persuazívna funkcia jazyka vo vzt’ahu k ideológii. Pozri KABÁT, Psychologie komunismu, s. 348-349.

${ }^{23}$ Porovnaj ČERMÁK, et al., Slovník komunistické totality, s. 25-29.

${ }^{24}$ Reprezentatívny korpus, na ktorom skúmame všeobecné jazykovo-komunikačné javy príznačné pre obdobia socializmu v 60. rokoch tvorí 232 textov z denníka Pravda z rokov 1961 - 1970. Texty korpusu boli vybrané náhodne, zvyčajne ide o prvý publikovaný úvodník a domáci komentár v každom mesiaci v priebehu desiatich rokov.
} 
nízkemu kvantitatívnemu zastúpeniu politických hesiel v danom korpuse, stále ide o dôležitú súčast' dobovej propagandy. Heslá sa vo svojom význame zameriavali na budovanie socialistickej spoločnosti smerujúcej ku komunizmu (v zmysle idealizovaného ciel'a) - Vít'azstvo komunizmu je nevyhnutné!; Nástup do jari komunizmu! ${ }^{25} \mathrm{~V}$ heslách, resp. výzvach sa objavoval tiež motív práce, ktorý zasahuje, okrem iného, aj do oblasti ideologického stereotypu. Na jednej strane vyzýva k práci a napredovaniu, ale zároveň upozorňuje na bližšie neurčeného, ale $\mathrm{v}$ dobovom kontexte zrejmého, nepriatel'a - Kde nepracujú komunisti, pracujú ich nepriatelia. ${ }^{26}$ Tematika hesiel vo všeobecnosti nezabúda ani na ekonomickú sféru a jej ideologické aspekty sústredené v centralizovanom a plánovanom hospodárstve - Socialisticky pracovat', socialisticky žit'!27 Nemožno vynechat' ani charakteristické slogany vyzývajúce k spolupráci so Sovietskym zväzom - Nech žije Sovietsky zväz!; So Sovietskym sväzom na večné časy!

Pri výskume $v$ reprezentatívnom korpuse sme zaznamenali zvýšený vplyv ideológie, nielen vo výskyte hesiel a sloganov, $\mathrm{v}$ textoch $\mathrm{s}$ tematickým zameraním a hlbším prepojením na ideologický kontext. To bolo motivujúcim faktorom pri konkretizácii výskumného zamerania na jazykové prejavy $\mathrm{v}$ heslách publikovaných $\mathrm{v}$ oficiálnej tlači v reakcii na vstup vojsk Varšavskej zmluvy do Československa 20. - 21. augusta 1968.

Výskumný priestor sme ohraničili obdobím od 21. augusta do 22. septembra 1968. Rozsah jedného mesiaca sme zvolili s ciel'om sledovat' množstvo, výskyt a tematickú diferenciáciu publikovaných hesiel, ale súčasne aj možnú významovú transformáciu v kontexte rýchlo prebiehajúcich zmien $v$ spoločnosti $v$ dňoch krátko po začiatku okupácie. Už predvýskum ukázal, že výskyt politicko-ideologických hesiel reagujúcich na aktuálne udalosti sa v dennej tlači realizoval v kratšom časovom horizonte. Dátum posledného zaznamenaného hesla sa pohybuje v čase 4. 12. septembra. Po 12. septembri sme žiadne d'alšie heslá už nezaznamenali a následne 26. septembra vstúpila do platnosti novelizácia tlačového zákona, ktorá rušila predchádzajúci zákaz cenzúry a sprísňovala kontrolu publikovaných informácií.

Materiál na výskum sme získali excerpciou zo šiestich slovenských celoštátnych aj regionálnych denníkov. Výsledný korpus predstavuje spolu sedemdesiat hesiel, ktoré sa nachádzali zvyčajne v záhlaví titulnej strany, v päte, príp. v inej časti novín (mimo jadra textu), čím sa podporovala pútacia funkcia tohto typu komunikátu. Východiskovú bázu predstavovali tieto denníky: Pravda - Ústredný orgán Komunistickej strany Slovenska (19 hesiel), Smena - Orgán slovenského ústredného výboru ČSM

\footnotetext{
${ }^{25}$ Nástup do jari komunizmu, In: Pravda, 1. máj 1961.

${ }^{26}$ Pôjdeme d’alej, In: Pravda, 1. októbra 1970.

${ }^{27}$ Nie výberové sút'až, In: Pravda, 1. apríl 1962.
} 
(16 hesiel), Východoslovenské noviny - Orgán východoslovenského krajského výboru KSS (13 hesiel), L'ud - Orgán strany Slovenskej obrody (12 hesiel) a Smer - Orgán stredoslovenského KV KSS (10 hesiel). Práca - denník Revolučného odborového hnutia neobsahoval žiadne heslá skúmaného typu a s výnimkou špeciálneho vydania $v$ dňoch 30 . - 31. augusta 1968 v nami ohraničenom období nevychádzal.

S ciel'om analyzovat' intertextový charakter tematicky orientovaných hesiel v politicko-ideologickom kontexte je na mieste bližšia charakteristika pojmu intertextovost', resp. intertextualita, pričom termíny chápeme ako synonymá. Ide o vnášanie iných textov alebo ich častí do textu novovznikajúceho. $V$ médiách sa využíva ako argumentačný nástroj a zarad'ujeme sem alúzie, citáty, parafrázy i príslovia. ${ }^{28}$ Vo vybranom materiáli prevládajú citáty, ale možno ich zaradit’ aj $\mathrm{k}$ alúzii v zmysle podprahového motívu, ktorý sa nachádza v jednotlivých heslách. Alúzia predstavuje priamy aj nepriamy odkaz na umelecký, historický, politický a iný kontext začlenený do stavby textu alebo menšej textovej jednotky. Autori v nej implicitne, ale aj explicitne vytvárali narážky v pozitívnom, ironickom aj odmietavom zmysle. Ich význam je pochopitel'ný iba pre adresáta oboznámeného s pôvodným textom (pretextom), na základe čoho sa v alúziách využívajú odkazy na známe politické, umelecké a literárne diela, resp. ich tvorcov. Ich ciel'om je zaujat' stanovisko k aktuálnemu dianiu, z čoho vyplýva, že sú tematicky prepojené s extralingválnymi podmienkami. Vo vzt'ahu k čitatel'ovi plnia nielen kontaktnú (pútaciu) a argumentačnú funkciu, ale v súlade s nimi vystupujú persuazívne a sú zdrojom kontextovej expresivity. ${ }^{29}$

Persuazívne tendencie, ktoré môžu byt' zároveň ideologicky motivované, vyplývajú z vol'by pretextov - sú to texty známe, väčšinou staršej proveniencie, ktoré tvoria súčast' kultúrneho dedičstva a všeobecného „know-how“ priemerného adresáta. Emócie a hodnotenia vyjadrené v alúziách a citátoch si nárokujú všeobecnejšiu platnost', v dôsledku čoho sa stávajú sugestívnejšími. ${ }^{30}$

Z hl'adiska metodologického prístupu k excerpovaným heslám z roku 1968 je v popredí kvalitatívna analýza materiálu. Z toho dôvodu pri konkretizácii analýzy vybranými príkladmi neuvádzame bližší bibliografický odkaz. V rámci výskumu je pre nás dominantné tematicko-sémantické a funkčné usúvzt’ažnenie publikovaných hesiel. Ich príslušnost' k jednotlivým periodikám, resp. ich umiestnenie v nich je sekundárne. Relevantným je v tejto situácii tiež fakt, že periodicita novín bola v období krátko

\footnotetext{
${ }^{28}$ MINÁŘOVÁ, E.: Stylistika pro žurnalisty. Praha : Grada, 2011, s. 231-232.

${ }^{29}$ JUNKOVÁ, B.: Jazyková dynamika současné publicistiky. Praha : ARSCI, 2010, s. 187-190.

30 KARHANOVÁ, K.: Funkce mezitextového navazování v novinách. In: Slovo a slovesnost, 1990 , roč. 60 , č. 1 , s. 34-35.
} 
po začiatku okupácie nepravidelná, skúmané noviny nemali štandardný formát a teda ani stránkovanie.

Uplatnený interpretačno-výkladový postup vo výskume vyplýva zo zamerania na sémantické aspekty jednotlivých hesiel a ich funkciu $v$ širšom kontexte historických udalostí, ku ktorým sa vzt'ahujú. V dôsledku interdisciplinárnych súvislostí sa bližšie zaoberáme najmä sociokultúrnou zložkou pretextov. Obsah a význam hesiel podmieňujúci ich zapojenie do kontextu roku 1968 často súvisí s otázkou autorstva pretextu a z toho odvodenou funkciou v rámci historických udalostí. Zohl'adňujeme tiež hodnotové a ideové zameranie citovaných osobností v zmysle ich príslušnosti k politickému, kultúrnemu či ideologickému prúdu - dobovo aktuálnemu, ale aj historicky staršiemu, ktorý poukazuje na bezprostredný kontext aluzívneho segmentu. ${ }^{31}$

\section{Výsledky analýzy politicko-ideologických hesiel k augustu 1968}

Na základe uvedeného analyticko-interpretačného prístupu k výskumnému materiálu rozlišujeme dve skupiny politicko-ideologických hesiel nachádzajúce sa vo vytvorenom korpuse. K prvej patria heslá publikované v okamžitej reakcii na vstup okupačných armád do Československa, to znamená v dňoch ihned' po noci z 20. - 21. augusta 1968. Vyznačujú sa absenciou autora a plurálovou formou, najčastejšie v prvej a druhej osobe. Ich celkový výskyt predstavuje dvadsat'dva príkladov zo sedemdesiatich (31,43 \% z celkového počtu). Pre danú skupinu hesiel je charakteristických niekol'ko opakujúcich sa motívov, ktoré sú v nich vyjadrené.

Na prvom mieste je zaznamenanie výrazného odporu voči invázii a príslušníkom okupačných armád, ktorý reflektujú príklady Nesúhlasili sme a nesúhlasíme s okupáciou! alebo PROTESTUJEME!, kde je sémantický dôraz podporený, okrem iného, využitím vel'kých písmen. Okrem vyjadrenia protestu a odporu voči vzniknutej situácii a jej účastníkom, je prítomný aj istý apel na medzil'udskú solidaritu, napr. Vojaci! Vy máte rodiny aj my. Nestriel'ajte do nás! Ak ste skutoční priatelia, vrát'te sa domov! Na druhom mieste je motív vytrvalosti národa zoči-voči nečakaným podmienkam a nestabilnej situácii, napr. Nedovol'me vniest' paniku do našich radov.; ZACHOVAŤ PRAVDU, ROZVAHU A DÔSTOJNOSŤ!!!; Nepripust'me rozkol v našich radoch! Motív vytrvalosti je vyjadrený vztiahnutím ku konkrétnym ideovým pilierom a spoločenským hodnotám režimu v tom čase, konkrétne tomto prípade k myšlienke udržania tzv. socializmu s l'udskou tvárou - Naša strana v nerozbornej jednote s l'udom nikdy neustúpi od myšlienky socializmu, humanizmu a národnej samostatnosti. Možno tu badat'

\footnotetext{
${ }^{31} \mathrm{~K}$ tomu pozri: HOMOLÁČ, J.: Intertextovost a utváření smyslu v textu. Praha : Karolinum, 1996, s. 68.
} 
typický ideologický a populistický aspekt v podobe kombinácie strana v spojení s l'udom.

Nechýbajú ani alúzie, resp. odkazy na vybrané momenty národnej histórie predstavujúce paralelu v oblasti kontextu či pertraktovaných hodnôt. V rámci vojenských dejín spätých s odporom je to najmä Slovenské národné povstanie vystupujúce v roku $1968 \mathrm{v}$ pozícii vzoru - Bud'me pevní a jednotní ako v SNP! Práve Slovenské národné povstanie patrí k významným socialistickým sviatkom a podobne ako Sviatok práce (1. máj) aj oslavy a pripomínanie SNP (29. august) boli dôležitou súčast'ou politickoideologického obrazu režimu. Boli reinterpretované v kontexte socialistickej ideológie a stali sa pevnou súčast'ou propagandy. Po februári 1948 sa začal formovat' nový mýtus o SNP prezentujúci ho ako začiatok na ceste $\mathrm{k}$ „št’astnej budúcnosti“. Zdôrazňovali sa najmä kladné vzt'ahy k Sovietskemu zväzu a odhalenie zradnej buržoáznej politiky. K uvol'neniu v diskusii o SNP došlo pod vplyvom vonkajších podmienok v roku 1968, ked' sa začalo hovorit' aj o negatívnych, dovtedy tabuizovaných stránkach povstania. Dočasným uvol'nením schematizmu možno vysvetlit' prienik motívov SNP do sloganov publikovaných pri začiatku okupácie. ${ }^{32}$

$\mathrm{V}$ podobnom význame je $\mathrm{v}$ heslách zastúpený motív jednoty s podtextom súdržnosti, solidárnosti a spolupatričnosti obyvatel'stva v boji proti nepriatel'ovi. Okrem toho sa v menšej miere vyskytol aj motív túžby po stabilite vyjadrený snahou normalizovat' podmienky života v spoločnosti a vrátit' sa ku každodenným povinnostiam - DO PRÁCE, NORMALIZOVAŤ ŽIVOT!; Odíd'te, chceme kl'udne pracovat'! Spoločným znakom všetkých hesiel v tejto kategórii je ich charakter zvolania a zakončenie výkričníkom, pridávajúcim dôraz vyjadrovanej myšlienke.

Druhú kategóriu v skúmanom korpuse predstavujú heslá publikované s časovým odstupom (približne dvoch týždňov) od vstupu vojsk Varšavskej zmluvy do Československa. V tomto období sa ich charakter transformuje zo všeobecnej výzvy adresovanej obyvatel'om na citát, v ktorom je zakomponovaná myšlienka s ústredným motívom viažucim sa k aktuálnej spoločensko-politickej, ale aj ideologickej situácii v krajine. Pri analýze prihliadame tak na tematiku a motivické kategórie zvolených citátov, ako aj na ich autorstvo. Ako sme naznačili v teoretických východiskách výskumu, ide o výroky známych osobností nárokujúcich si

\footnotetext{
32 Plurálne spomínanie na udalosti SNP ukončila začínajúca normalizácia od roku 1969, ktorá zafixovala jedinú oficiálnu „národno-komunistickú“ interpretáciu kanonizovanú v spomienkach G. Husáka z roku 1964. Až do roku 1989 sa potom oslavovala predovšetkým vedúca úloha strany a teleologický výklad SNP ako revolučného míl'nika na ceste k socializmu. Porovnaj MANNOVÁ, E.: Slovenské národné povstanie a politická pamät'. In: IVANIČKOVÁ, E. et al.: Z dejín demokratických a totalitných režimov na Slovensku a v Československu v 20. storočí. Bratislava : Historický ústav SAV vo vydaval'stve Prodama, 2008, s. 215-230.
} 
všeobecnú platnost'. Na tomto mieste možno doplnit' tvrdenie, podl'a ktorého „jeden z ustálených popisů Pražského jara vychází z predstavy, že šlo o reformní hnutí, které se opíralo o silnou podporu intelektuálů, vědců a umělců. Toto pojetí pěkně zapadá do českého národního autostereotypu, podle něhož právě kulturní obec prèedstavovala již od národního hnutí devatenáctého století hlavní sílu společenského pohybu". ${ }^{33} \mathrm{~V}$ súvislosti s citovaným názorom poukážeme nižšie na vplyv osobností z intelektuálneho a kultúrneho prostredia, ako aj špecificky na silný dôraz 19. storočia.

V otázke autorstva zvolených výrokov v dennej tlači sme zaznamenali dve skupiny rozdel'ujúce citované osobnosti na politické a literárne. K citovaným politikom patria tí, ktorí boli činní v roku 1968 na najvyšších štátnych a straníckych pozíciách a priamo zapojení do riešenia vzniknutej situácie spojenej s vojenskou inváziou aj nasledujúcimi rokovaniami medzi predstavitel'mi Československa a Sovietskeho zväzu. Patrili k nim československý prezident L. Svoboda, prvý tajomník ÚV KSČ A. Dubček a člen Predsedníctva ÚV KSČ G. Husák. Na druhej strane sa $\mathrm{v}$ tejto skupine vyskytovali tiež vedúce osobnosti reprezentujúce marxisticko-leninskú ideológiu - K. Marx, F. Engels a V. I. Lenin. Kým u ostatných menovaných $\mathrm{v}$ oboch skupinách nie je konkretizovaný zdroj zvoleného citátu, v prípade Lenina je pri heslách doplnený odkaz na vybranú čast' jeho Spisov. Špecifickou kategóriou sú politicky činné osoby z domácej, ale i zahraničnej histórie, ktoré boli zvolené pravdepodobne pre ich tematickú usúvzt’ažnenost' s podobnými udalost'ami v histórii. Možno tak hovorit' o prítomnosti alúzie už v samotnom procese vol'by citovanej osobnosti, ktorá je následne podporená vhodne vybraným výrokom. K týmto osobnostiam vyskytujúcim sa v skúmanom materiáli zarad'ujeme M. R. Štefánika, C. Desmoulinsa, Owena D. Younga a Johna Stuarta Milla.

M. R. Štefánik (1880 - 1919) zastával v danom období a špeciálne v kontexte roku 1968 dôležité miesto. V dôsledku mýtizácie a sakralizácie jeho osoby sa stal po roku 1919 súčast'ou národného panteónu slovenských hrdinov. ${ }^{34}$ Jeho osobnost' a odkaz v historickej pamäti prešli istým vývojom pod vplyvom marxistickej historiografie po roku 1948. Štefánik a jeho prínos v rámci formovania prvej ČSR boli pre ideológiu socializmu neprijatel'né a v nových podmienkach vyžadovali zmenu pod transformáciu štefánikovskej legendy sa podpísal historik L'. Holotík.

\footnotetext{
${ }^{33}$ KOLÁǨ, P.: Pražské jaro jako průsečník evropských duchovních dějin aneb budoucnost mezi Richtou a Grausem. In: KOLÁŘ, P. - PULLMANN, M.: Co byla normalizace? Studie o pozdním socialismu. Praha : Lidové noviny, 2016, s. 146.

${ }^{34} \mathrm{O}$ postupnom rozvíjaní a formovaní štefánikovského mýtu ako súčasti historickej pamäti slovenského národa od vzniku prvej ČSR až do súčasnosti pozri MACHO, P.: Milan Rastislav Štefánik - bohatier a mučeník? In: KREKOVIČ, E. - MANNOVÁ, E. - KREKOVIČOVÁ, E.: Mýty naše slovenské. Bratislava : Premedia, 2005, s. 163-173.
} 
Štefánika považoval za antikomunistu a služobníka francúzskeho imperializmu, čo najvýraznejšie rozpracoval v knihe Štefánikovská legenda a vznik $\breve{C} S R{ }^{35}$ Toto dielo vyvolalo prudkú kritiku v dennej tlači práve v uvol'nenom období roku 1968. ${ }^{36}$ Snahy o rehabilitáciu Štefánikovej osobnosti a diela spojené s propagovaním federalizácie boli predmetom manifestácie na Bradle 4. - 5. mája 1968. Išlo o jeden z najvýznamnejších prejavov prebúdzajúcej sa spoločnosti, ked’ bolo zároveň možné znovu si po 20 rokoch uctit' spomienku na túto osobnost' slovenských aj československých dejín. ${ }^{37}$

V tomto kontexte je vol'ba citovat' práve M. R. Štefánika v reakcii na inváziu sovietskych vojsk do Československa celkom zrejmá. Jeho politické, mravné i etické krédo VERIŤ, MILOVAŤ, PRACOVAŤ sa v auguste 1968 stalo heslom odkazujúcim k zásadným spoločenským hodnotám, ale aj k myšlienkam československej samostatnosti, za ktorú Štefánik bojoval a ktorá podliehala priamej hrozbe.

S obdobím prvej svetovej vojny súvisí tiež osobnost' a činnost' Owena D. Younga (1874 - 1962), amerického právnika a podnikatel'a, ktorý je známy svojou snahou o vyriešenie reparačných problémov a reformami smerujúcimi k stabilizácii nemeckej meny v povojnovej Európe (v roku 1929 vstúpil do platnosti tzv. Youngov plán). V jeho citovanom výroku, ktorý sa objavil v denníku L’ud, sa v kontexte doby zdôrazňuje predovšetkým intolerancia Sovietskeho zväzu voči novým ideám a pokusom o reformné smerovanie socializmu v Československu - Kto sa dokáže vžit' do cudzej osobnosti, kto dokáže pochopit' cudzie myšlienky, ten nemusí mat' starost' o budúcnost'. Ergo, invázia do Československa je interpretovaná ako dôsledok nepochopenia, z ktorého vyplývali obavy o udržanie politicko-ideologickej stability a vplyvu Sovietskeho zväzu.

Chronologicky staršími osobnost'ami sú C. Desmoulins (1760 1794), účastník Vel'kej francúzskej revolúcie a blízky spolupracovník G. Dantona, a J. S. Mill (1806 - 1873), britský filozof a jeden z najvplyvnejších myslitel'ov v oblasti klasického liberalizmu. Kým v prípade Desmoulinsa vystupuje do popredia jeho revolučná činnost' usúvzt'ažnitel'ná s vyjadrením odporu obyvatel'stva ČSSR proti okupantom, za spoločný motív možno považovat' myšlienku slobody a liberalizmu, ktorá je jadrom oboch citovaných výrokov - Tyrani všetkých odtieňov sa boja myšlienok o slobode viac ako bajonetov (C. Desmoulins); Láska k moci a láska

\footnotetext{
${ }^{35}$ HOLOTÍK, L'.: Štefánikovská legenda a vznik ČSR. Bratislava : Vydavatel'stvo SAV, 1960. $535 \mathrm{~s}$.

${ }^{36}$ Bližšie $\mathrm{k}$ tejto téme a priebehu diskusie medzi redaktormi slovenských denníkov a L. Holotíkom pozri RíMEŠOVÁ, M.: Postava slovenského marxistického historika L'udovíta Holotíka a jeho „kauzy“ v slovenskej historiografii. In: Pamät’ národa, 2020, č. 2, s. 22-38.

${ }^{37}$ Viac k manifestácii a jej priebehu pozri PEŠEK, August 1968..., s. 114-115.
} 
k slobode sú vo večnom spore (John Stuart Mill). V citátoch sú explicitne prítomné alúzie na totalitný postoj Sovietskeho zväzu, reformy Pražskej jari a obavy z narušenia oficiálnej ideologickej základne, čo by znamenalo možnú zmenu mocenských pozícií.

Pri pohl'ade na druhú vyčlenenú skupinu citovaných osobností môžeme konštatovat', že rozsah autorov z literárnej oblasti je značne obsiahlejší a viac chronologicky diferencovaný ako tomu bolo v kategórii politikov. Nachádzame tu odkazy na literátov od antiky až do 20. storočia, a to tak domácich, ako aj svetových, pričom nie je náhodný ani výber jednotlivých období z literárnych dejín. Z hl'adiska ich členenia sú zastúpení predstavitelia antiky (Cicero, 106 - 43 pred n. l.; L. Seneca, c. 4 pred n. l. - 65), renesancie (W. Shakespeare, 1564 - 1616), baroka (Lope de Vega, 1562 - 1635), osvietenstva (J. J. Rousseau, 1712 - 1778), autori z 19. storočia (V. Hugo,1802 - 1885; P. Valéry, 1871 - 1945; J. Tuwim, 1894 - 1953; A. Zweig, 1887 - 1968) aj z 20. storočia (A. de SaintExupéry, 1900 - 1944; J. P. Sartre, 1905 - 1980; M. Gorkij, 1868 - 1936). Môžeme si všimnút', že najmä pri autoroch posledných dvoch storočí nie je jednotiacim faktorom ich doba či život, ale tematické zameranie literatúry 19. a 20. storočia. V zastúpených smeroch staršej literárnej proveniencie je viditel'ný príklon k racionalizmu (s výnimkou baroka), pričom myšlienkové smery 19. storočia sa v politickej, filozofickej aj literárnej sfére orientovali primárne na národnooslobodzovacie hnutie rozšírené $\mathrm{v}$ Európe. $\mathrm{V}$ dôsledku toho sa $\mathrm{v}$ literárnych dielach reflektovali myšlienky slobody, samostatnosti a rovnoprávnosti, ktoré následne našli uplatnenie aj v skúmanom období roku 1968. V špecifickej podobe možno vnímat' tematické a ideové smerovanie v podmienkach slovenskej literatúry 19. storočia, kde bola tematika samostatnosti a zvrchovanosti národa mimoriadne silná, a to najmä pôsobením osobností ako štúrovci, J. Kollár, J. Hollý a d’alší. Práve J. Kollár, A. Sládkovič a L'. Štúr sa vyskytovali aj medzi autormi citátov v tlači v auguste 1968. Autori z 19. storočia sú v skúmanej vzorke výrazne zastúpení, v dôsledku čoho môžeme predpokladat', že podnetom k ich výberu bol revolučný charakter tej doby spájaný s už známymi motívmi slobody, oslobodenia, samostatnosti a budovania národnej identity.

Pri zhodnotení literátov z 20. storočia vidiet', že ich výber rovnako nebol náhodný. Exupéry sa do dejín literatúry zapísal filozofickým príbehom Malý princ s výraznou spoločenskou kritikou. Existencializmus, ktorého hlavným predstavitel'om je J. P. Sartre sa vyznačuje individualizmom a analýzou konania človeka v spoločnosti, najmä v hraničných situáciách, bojom proti konvenciám, presadzovaním osobnej vôle, slobody a hl'adaním zmyslu bytia. V oboch prípadoch sú implicitne zhrnuté alúzie k skúmaným augustovým udalostiam v Československu a hoci 
M. Gorkij je v literárnom kontexte reprezentantom socialistického realizmu, vzhl'adom na zvolený výrok (Lebo nič nemrzačí človeka tak strašne ako trpezlivé, pokorné podrobovanie sa sile vonkajších okolností.) možno jeho interpretáciu smerovat' skôr k autorovým revolučným tendenciám v osobnom živote.

V kategórii výrokov s konkretizovaným autorstvom sme priblížili základnú diferenciáciu $\mathrm{z}$ hl'adiska autorskej príslušnosti k politickej a literárnej sfére, rovnako ako pôsobenie v ich rámci. Druhý uhol pohl'adu predstavuje výber motívov tematického zamerania skúmaných hesiel a výrokov. V neautorských sloganoch denníka Pravda možno zaznamenat' (okrem vyššie analyzovaných) motív pravdy ako obraňovanej a požadovanej hodnoty, napr. S DUBČEKOM A SVOBODOM! PRAVDA ZVÍŤTZÍ!; Je l'ahšie pravdu do tváre udriet', ako sa jej do tváre pozriet'. K zastúpeným tematickým okruhom patria d'alej hlavne sloboda, ale aj hodnotenie a vyjadrenie postoja k okupácii, zdôrazňovanie československej cesty k vlastnej forme socializmu a v neposlednom rade reflexia aktuálnej situácie v Československu.

Pri bližšej analýze možno vidiet', že vzhl'adom na spoločensko-politický kontext dominuje motív slobody vnímanej v pozícii ciel'a, ideálu, ale aj hodnoty. Vystupuje v zmysle základného práva občana/štátu v spojení s princípom štátnej suverenity, ale na druhej strane sa formou daného motívu poukazuje na porušovanie slobodnej vol'by a slobodného rozhodovania. Pre ilustráciu vyberáme niekol'ko príkladov:

K slobode patrí nielen to, čím žijem, ale i to, ako žijem; nielen to, že konám slobodne, ale aj to, čo konám slobodne. - K. Marx

SÁM SVOBODY KDO HODEN, SVOBODU ZNÁ VÁŽIT KAŽDOU. - J. Kollár

Na čo je sloboda, ak nie na to, aby si sa angažoval? - J. P. Sartre

S narušením tejto domény úzko súvisia vybrané citáty $\mathrm{k}$ vojenskej intervencii a okupácii krajiny zachytávajúce postoj k nej prostredníctvom alúzií v myšlienkach známych literátov a politikov. V rámci tohto okruhu môžeme pozorovat' odkazy na zneužitie moci v kontexte vojenského intervenčného zásahu, napr. vo výrokoch K. Marxa - Medzi dvoma rovnakými právami rozhoduje moc.; Účel, ktorý potrebuje nesprávne prostriedky, nemôže byt'správny. Tie sa d'alej rozvíjajú a usúvzt'ažňujú motívom pocit'ovanej zrady v realizácii tzv. bratskej pomoci - Nemožno vôbec ospravedlnit' zlo, hoci sa urobilo v mene priatel'stva. - Cicero; Nemarte čas hl'adaním príčin nel'udskosti: všetky sa v dejinách spáchali za plat. - Pascal. Dlhodobo vzájomne napäté vzt'ahy Československa a Sovietskeho zväzu, ktoré vyvrcholili v auguste 1968, reflektujú formou skúmaných hesiel a výrokov aj neúspešné snahy reformného obdobia o transformáciu socializmu v krajine. Súčast'ou hodnotenia v danom okruhu je sovietska 
intolerancia k politicko-ideologickej situácii v Československu. Reakcia Sovietskeho zväzu je koncipovaná v podobe závisti a neprajnosti:

ÚSPECH JE NIEČO, ČO TI PRIATELIA NIKDY NEODPUSTIA - TUwim A čo ked'sa ten puk vo kvet rozvije? Svety nám závidiet' budú. A. Sládkovič

Tretím prítomným motívom nachádzajúcim sa v skúmanom materiáli je zdôrazňovanie, resp. príklon k vlastnej špecifickej československej ceste k socializmu, teda k reformám a demokratizačnému procesu. Do popredia vystupuje obhajoba vzniknutého stavu, z ktorej možno odvodit' lojalitu obyvatel'stva k reformnému napredovaniu a jeho podporu v súčasnej kritickej situácii. K základným preferovaným pilierom spoločnosti v socialistickom Československu po tzv. Pražskej jari patria reformné tendencie v politickom smerovaní, na ktoré sa d’alej explicitne odkazuje vo vybraných výrokoch. Konkrétne ide o Akčný program KSČ a všeobecné smerovanie politiky v kontexte budovania socializmu s l'udskou tvárou. Charakteristickým aspektom je, že tento motív nie je vyzdvihovaný literárnymi, ale politickými predstavitel'mi, medzi ktorými sa viackrát opakuje meno G. Husáka, ktorý bol od 26. augusta 1968 prvým tajomníkom ÚV KSS:

Boli sme pevnou súčast'ou KSČS a hlásime sa k zodpovednosti nielen za vývoj na Slovensku, ale i k zodpovednosti za osudy československého štátu a celej našej komunistickej strany Československa. - G. Husák

Hlásime sa k pojanuárovemu prúdu našej strany, k tomu, čo nazývame demokratizačný proces. - G. Husák

Hlásime sa k akčnému programu a jeho ustanovenia budeme uvádzat' do života, realizovat' a spresňovat'. - dr. Gustáv Husák

Rovnaký motív bol prezentovaný v citáte prezidenta L. Svobodu, ktorý rovnako ako Husák vyjadril zámer udržat' vývinové tendencie v línii reformného programu - Program pojanuároveho vývoja musí zostat' podl'a vôle strany i národov našej krajiny našou generálnou líniou. Nikto $\mathrm{z}$ d'alších čelných predstavitel'ov československej vlády nebol v skúmaných periodikách citovaný. Možno však uviest', že niekol'kokrát rezonovali výroky zo Spisov V. I. Lenina, ktoré zámerne zdôrazňovali myšlienky vodcu bol'ševickej revolúcie v roku 1917, sústredené okolo motívu inovácie a budovania novej, individuálnej cesty. Tým sa zároveň reflektuje jedna zo základných budovatel'ských metafor socialistického režimu v danom období - metafora cesty zobrazujúca socializmus ako vývojovú etapu so zámerom dosiahnut' ciel' v podobe komunizmu. Svojim obsahom boli tieto výroky aktuálne k situácii v Československu a vzhl'adom na konkretizovaný zdroj možno ich výber považovat' za snahu predkladat' silné, ideologicky podporené argumenty: 
Treba vediet' pracovat' na novej ceste. Je to nepomerne t'ažšie, no vôbec nie beznádejné. - V. I. Lenin

Votázke sebaurčenia národov spočíva podstata veci v tom, že rozličné národy kráčajú po rovnakej historickej ceste, no vel'mi rozmanitými chodníčkami a okl'ukami, že kultúrnejšie národy idú vedome inak, než menej kultúrne. - V. I. Lenin, Spisy 29, s. 169.

Posledným motívom vyskytujúcim sa v skúmanom korpuse politických hesiel je reflexia domácej situácie prostredníctvom alúzií na činnost' obyvatel'stva a jeho postoj k vzniknutým spoločenským podmienkam. Jej základnou a smerodajnou myšlienkou je princíp vernosti a to tak k národu, ako aj k ideám československého socializmu, napr. Láska $k$ vlasti nepozná žiadne stupne. Alebo sa celý oddám práci, alebo nerobím nič pre vlast'. - Börne; Vernost' je ovenčená činmi, nie slovami. - Shakespeare. Ani v tejto skupine nechýba motív slobody, hoci vo výroku J. J. Rousseaua vystupuje do popredia aj aspekt obetovania slobody $\mathrm{v}$ prospech vyššieho morálneho princípu, ako na to poukazuje príklad Okovy sú zo zlata, ak ich človek nosí pre obhajovanie l'udskosti. Podobnú interpretačnú rovinu možno zaznamenat' aj v d'alšom príklade od L. Senecu, ktorý je postavený na morálnej vel'kosti porazeného - Radšej chcem byt' porazený $v$ dobrom, než zvít'azit'v zlom. V týchto výrokoch vnímame istú opozíciu na úrovni vít’azstvo $\leftrightarrow$ porážka v zmysle uvedomenia si bezvýchodiskovosti situácie na jednej strane, ale zároveň snahu o Pyrrhovo vít’azstvo aspoň z hl'adiska morálnej neústupnosti.

Záver. Politicko-ideologické heslá a výroky nachádzajúce sa v dennej tlači sú súčast'ou jazyka obdobia socializmu v oficiálnom mediálnom diskurze 60. rokov. Tematickým vymedzením sme vytvorili súbor sedemdesiatich príkladov reagujúcich na inváziu vojsk Varšavskej zmluvy do Československa v auguste 1968 . Heslá boli publikované v piatich celoštátnych a regionálnych periodikách v rozmedzí od 21. augusta do (najneskôr) 12. septembra 1968. Na základe analyticko-interpretačného prístupu k materiálu sme vymedzili heslá uverejnené okamžite po začiatku okupácie a následne autorské výroky literárnych a politických osobností, ktoré sa vyskytovali v istým časovým odstupom.

Prvá skupina hesiel bez uvedenia autora zaznamenaná ihned' po obsadení Československa vyjadrovala odpor domáceho obyvatel'stva voči neočakávanej vojenskej intervencii a poukazovala na základné hodnoty československej spoločnosti. Vzhl’adom na tematicko-sémantickú analýzu sme medzi nimi identifikovali vytrvalost', jednotu a vernost' národa. Boli spojení s výzvami a povzbudeniami vyjadrujúcimi podporu vedúcim predstavitel'om československej vlády A. Dubčekovi a L. Svobodovi, v menšej miere tiež O. Černíkovi a J. Smrkovskému. Vyznačovali sa vyšším stupňom 
emotívnosti, ktorý sa v jazykovej rovine odzrkadlil v používaní verzál a výkričníkov, čo nie je netypické pre texty publikované v krízovej situácii. Princíp jednoty národa a vzájomnej solidarity zdôrazňovala plurálová forma slovies či v neurčitok v prípade zvolania, ktoré možno interpretovat' v zmysle vyburcovaných emócií.

Druhú skupinu predstavovali výroky významných politických a literárnych osobností s politickým, dejinným či kultúrnym odkazom na vzniknutú situáciu v Československu. Ide najmä o výroky vedúcich politických predstavitel'ov strany, štátu a marxisticko-leninskej ideológie. Výber d'alších citovaných osobností podmienený spoločensko-politickým zaangažovaním v boji za slobodu a proti útlaku v rôznych historických obdobiach. Rovnaký motív rezonuje aj medzi zastúpenými literátmi od antiky až do 20. storočia. Vychádzajúc z výskumných zistení môžeme konštatovat', že k najvýraznejším motívom, ktoré sa v alúziách oboch skupín hesiel vyskytovali, patrili hodnoty pravdy a slobody. Vzhl'adom na turbulentný vývoj v prvých týždňoch okupácie sa práve tieto hodnoty považovali za najviac ohrozené, a to nielen $v$ dôsledku vojenskej invázie, ale aj s prihliadnutím na pretrvávajúci postoj Sovietskeho zväzu k vývoju v krajine, snahám o demokratizáciu spoločnosti a presadzovaniu tzv. socializmu s l'udskou tvárou. S tým súvisí túžba obraňovat' a chránit' budovanie vlastnej socialistickej cesty a kritika Sovietskeho zväzu v spojení s atribútmi zrady, ktoré sa reflektovali v citátoch z Leninových spisov a diel d'alších osobností marxizmu-leninizmu.

Tematicko-sémantická analýza politických hesiel publikovaných v reakcii na inváziu vojsk Varšavskej zmluvy do Československa zaznamenáva jeden z mnohých odrazov vonkajšieho ideologického prostredia $v$ jazyku. Získané výsledky umožňujú prehíbit' interdisciplinárny výskum jazyka obdobia socializmu v rámci oficiálneho diskurzu 60. rokov. Zároveň tu možno poukázat’ na fakt, že reflexia extralingválnych aspektov je explicitne prítomná aj v menších textových jednotkách. Heslá a slogany predstavujú jeden $\mathrm{z}$ charakteristických prvkov totalitného jazyka podporujúc jeho príznačnú strnulost', schematickost' a dôraz na propagandu. Napriek tomu je pohl'ad na ne prezentovaný v štúdii odlišný. Heslá a výroky obsahujúce alúzie tu vystupujú nie ako prejav režimovej propagandy, ale vo funkcii hlasu l'udu vyjadrujúceho reakciu či stanovisko k vzniknutej situácii vo výnimočných podmienkach dočasne uvol'nenej cenzúry. Ďalším dôležitým faktom je ich spätost' s obdobím krízy, čo sa prejavuje zvýšeným kvantitatívnym výskytom v krátkom časovom rozsahu. Na základe tohto príkladu možno uvažovat', či majú aj iné udalosti v priebehu socialistickej etapy československých dejín podobné tendencie v jazykovej rovine, alebo či ide o výnimočný prejav vyplývajúci z predchádzajúceho vývinu a pokusov o modifikáciu ideologického systému? 